\author{
Robert Szmytkie \\ https://orcid.org/0000-0001-6415-9342 \\ Uniwersytet Wrocławski \\ Zakład Geografii Społeczno-Ekonomicznej \\ robert.szmytkie@uwr.edu.pl
}

\title{
ZMIANY GRANIC ADMINISTRACYJNYCH MIAST W POLSCE W LATACH 1990-2017 I ICH WPŁYW NA WIELKOŚĆ ZALUDNIENIA
}

\begin{abstract}
Abstrakt: Głównym celem autora artykułu jest określenie wpływu odrodzenia się samorządności lokalnej w Polsce na zmiany granic administracyjnych miast po 1990 r. Badaniami objęto miasta funkcjonujące w latach 1945-2018 (1041 jednostek), a ich istotą było zebranie informacji na temat wszystkich zmian granic administracyjnych miast $w$ okresie powojennym. Uwzględniono jedynie zmiany związane $\mathrm{z}$ wcieleniem lub wyłączeniem z granic miast innych miejscowości, pomijając tym samym zmiany granic miast związane ze zmianą przynależności administracyjnej terenów niezurbanizowanych. W efekcie stwierdzono, że po 1989 r. intensywność zmian granic administracyjnych miast w Polsce znacząco zmniejszyła się w stosunku do okresu poprzedzającego (lata 1945-1989). Wyróżniono trzy zasadnicze tendencje współczesnych zmian administracyjnych miast: rozpad miast-zlepieńców, rozpad zlepieńców miejsko-wiejskich i wcielanie w granice miast podmiejskich wsi.
\end{abstract}

Słowa kluczowe: zmiany administracyjne miast, miasta-zlepieńce, zlepieńce miejsko-wiejskie, procesy inkorporacji, Polska.

\section{ADMINISTRATIVE BORDERS CHANGES OF TOWNS AND CITIES IN POLAND IN THE YEARS 1990-2017}

Abstract: The main objective of the article is to determine the impact of the revival of local self-government in Poland on changes in the administrative borders of towns and cities after 1990. The research covered towns functioning in the years 1945-2018 (1041 units). The essence of the research was to collect information on all administrative border changes of towns and cities that took place in the post-war period. Only changes related to the incorporation or secession of other settlements from the borders of towns and cities have been taken into account, thus disregarding changes related to the change of administrative affiliation of non-urbanized areas. On the basis of the research, it was found that after 1989 the intensity of administrative borders changes of towns and cities in Poland decreased significantly compared to the previous period (1945-1989). Three basic tendencies of contemporary administrative changes of towns and cities were also distinguished: the disintegration of city conglomerates, the disintegration of urban-rural conglomerates and the incorporation of suburban villages into the administrative borders of cities.

Keywords: administrative changes of towns, city conglomerates, urban-rural conglomerates, incorporation processes, Poland.

\section{WPROWADZENIE}

W Polsce w latach 1945-1989 miały miejsce znaczące zmiany administracyjne miast zarówno w zakresie zmian liczby miast, jak i zmian ich granic administracyjnych. Największy wzrost powierzchni wystąpił w miastach dużych i średniej wielkości położonych $\mathrm{w}$ regionach podlegających intensywnym procesom industrializacji (Szmytkie, 2014; Szymańska, Grzelak-Kostulska, Hołowiecka, 2006, 2009), a także w ośrodkach, które w wyniku reformy podziału terytorialnego kraju w 1975 r. awansowały do grona miast wojewódzkich (Jelonek, Zborowski,
1992). Po 1977 r. dynamika zmian administracyjnych miast w Polsce uległa wyraźnemu zmniejszaniu (por. Powierzchnia i ludność..., 1994). Nowe uwarunkowania $\mathrm{w}$ tym zakresie przyniosło wprowadzenie w 1990 r. Ustawy o samorządzie gminnym, co przyczyniło się do wzrostu świadomości lokalnej (Kaczmarek, 2016). W tym kontekście istotne wydaje się pytanie o wplyw odrodzenia się samorządności lokalnej na zmiany granic administracyjnych miast po 1989 r. Odpowiedź na to pytanie jest głównym celem niniejszego opracowania. 


\section{ZMIANY GRANIC ADMINISTRACYJNYCH - ZAGADNIENIA TEORETYCZNE}

Według Kaczmarka (2005) zmiany administracyjne jednostek terytorialnych moga powodować: modyfikację liczby gmin (poprzez ich redukcję lub zwiększanie) lub zmianę ich granic. Zmiany granic administracyjnych jednostek lokalnych mogą zatem przybierać różne formy:

a) secesji - odłączenia się części jednostki i utworzenie nowej jednostki terytorialnej;

b) komasacji (amalgamacja, fuzja) - połączenia lub scalenia jednostek, czyli tworzenia nowej, większej jednostki, zwykle $\mathrm{z}$ dwóch lub większej liczby sąsiednich jednostek;

c) aneksji - włączenia, zwykle przez większą jednostkę, całości lub części terytorium mniejszej jednostki;

d) fragmentacji - likwidacji jednostki poprzez podział jej terytorium między sąsiadujące $\mathrm{z}$ nią jednostki;

e) parcelacji - podziału jednostki na dwie lub większą liczbę jednostek;

f) kreacji - tworzenia nowej jednostki na bazie terytoriów utraconych przez sąsiednie jednostki (rys. 1).

Jelonek i Zborowski (1992) wyróżniają trzy rodzaje zmian administracyjnych miast: powodujące wzrost lub ubytek liczby ludności miejskiej oraz niepowodujące zmian w liczbie ludności miejskiej. Uwzględniając wpływ poszczególnych zmian administracyjnych na zmiany liczby miast oraz zmiany liczby ludności miejskiej można wyróżnić sześć zasadniczych tendencji (tab. 1).

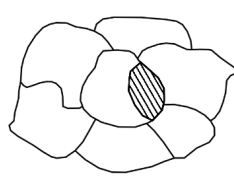

secesja

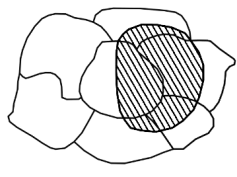

kreacja

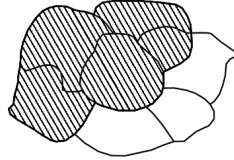

komasacja

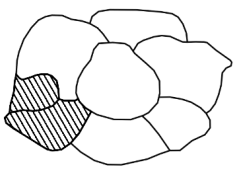

fragmentacja

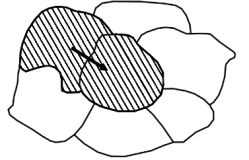

aneksja

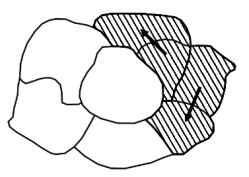

parcelacja $\square$ terytorium przed zmianą $\quad$ MIIU terytorium po zmianie

Rys. 1. Formy zmian granic administracyjnych jednostek terytorialnych

Źródło: opracowanie własne na podstawie Kaczmarek (2005)

Zmiany granic administracyjnych (rozwój terytorialny) są jednym z przejawów rozwoju miasta. Miasta nie mogą bowiem rozwijać się bez końca w obrębie swoich pierwotnych granic. Postępujący rozwój urbanistyczny może w końcu doprowadzić do zagospodarowania całego dotychczasowego obszaru miasta, w wyniku czego powstanie zapotrzebowanie na nową (zwykle mniej intensywnie użytkowaną) przestrzeń, która umożliwia jego dalszy rozwój przestrzenny. Nowa przestrzeń pozyskiwana jest w wyniku poszerzenia granic administracyjnych miasta. Przyczynia się to do zwiększenia powierzchni miasta i do spadku gęstości zaludnienia w jego granicach, a gdy zmiana granic obejmuje też obszary zamieszkane (inkorporacja miejscowości w granice miasta) - również do wzrostu liczby ludności miejskiej. Rozwój terytorialny miasta może także następować w oderwaniu od kierunków jego rozwoju przestrzennego. Skutkuje to wcieleniem w granice miasta terenów faktycznie słabo z nim

Tab. 1. Typologia zmian administracyjnych miast $\mathrm{z}$ uwagi na ich wpływ na zmiany liczby miast i zmiany liczby ludności miejskiej

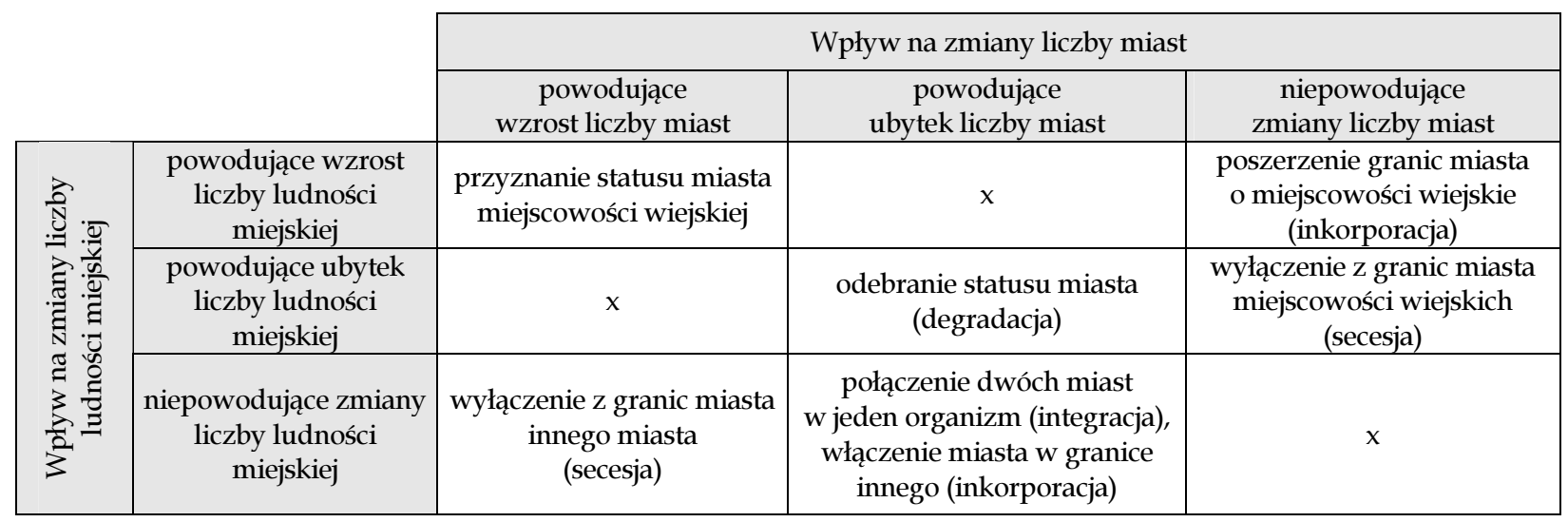

Źródło: opracowanie własne. 
powiązanych, głównie terenów użytkowanych ekstensywnie, ale też miejscowości, które mimo upływu czasu od inkorporacji zachowują odrębność i pierwotny charakter. Może to przyczynić się do korekt przebiegu granic administracyjnych miasta poprzez wyłączenie tych terenów (miejscowości).

W Polsce miasta stanowią odrębne jednostki terytorialne (gminy miejskie) lub siedziby gmin miejsko-wiejskich, w ramach których wyodrębnia się część miejską (miasto) i wiejską (miejscowości wiejskie). Granice miasta są ściśle określone, a ich zmiana podlega określonej procedurze. Według wspomnianej już Ustawy o samorzadzie gminnym $\mathrm{z}$ roku 1990 kompetencje w zakresie tworzenia, łączenia, dzielenia i znoszenia gmin, a także w zakresie nadawania gminie lub miejscowości statusu miasta i ustalania jego granic, posiada wyłącznie Rada Ministrów. W przypadku ustalania lub zmiany granic gmin pozytywne rozpatrzenie wniosku musi stosować się do następujących wymogów (Sobota, Jawecki, Tokarczyk-Dorociak, 2012):

1) maksymalnej jednorodności (spójności) terytorialnej poprzez analizę układu osadniczego i przestrzennego $\mathrm{w}$ zakresie występowania więzi społecznych, gospodarczych i kulturowych;

2) kształtowania granic jednostek podziału terytorialnego w sposób, który zapewni zdolność wykonywania zadań publicznych.

Zmiana granic administracyjnych miasta powinna również uwzględniać przesłanki: funkcjonalno-przestrzenne (występowanie powiązań z miastem przez infrastrukturę techniczną i komunikacyjną, charakterystykę procesów przestrzennych, potrzeby rozwojowe miasta) oraz społeczne (wyniki konsultacji społecznych, opinie właściwych rad i wojewody).

\section{METODY BADAŃ I ŹRÓDŁA DANYCH}

Badaniami w zakresie zmian administracyjnych objęto wszystkie miasta w Polsce istniejące $w$ latach 1945-2018, funkcjonujące zarówno przez cały analizowany okres, jak i te, które w jego trakcie uzyskały lub straciły status miasta (osiedla) bądź utracily samodzielność administracyjną. W sumie to 1041 miejscowości. Istotą badań było zebranie informacji na temat wszystkich zmian granic administracyjnych miast, które miały miejsce $\mathrm{w}$ okresie od 1945 do 2018 r. Uwzględniono jedynie zmiany związane $\mathrm{z}$ wcieleniem lub wyłączeniem $\mathrm{z}$ granic miast innych miejscowości (wsi, miast lub osiedli), pomijając tym samym zmiany granic miast związane ze zmianą przynależności administracyjnej terenów niezurbanizowanych (tzn. użytków rolnych, lasów, akwenów i nieużytków). Wyróżniono dwie kategorie zmian granic administracyjnych miast: inkorporację - rozumianą jako wcielenie $w$ granice miasta innej miejscowości, zwykle mniejszej (wsi, miasta lub osiedla), oraz secesję - definiowaną jako wyłączenie z granic miasta jednostki osadniczej (miejscowości), związane z odzyskaniem przez nią samodzielności administracyjnej. Wymagało to analizy kilkuset rozporządzeń zawartych w Dziennikach Ustaw Rzeczpospolitej Polskiej, ustanawiających poszczególne zmiany administracyjne. Jednocześnie w celu ukazania skali zjawiska skorzystano z danych GUS na temat zmian liczby ludności miejskiej, wywołanych przez zmiany administracyjne miast, dzięki czemu zobrazowano skalę i zmienność czasową analizowanego zjawiska. Aby zweryfikować różnice, jakie występowały i występują w zakresie zmian granic administracyjnych miast $\mathrm{w}$ okresie socjalizmu i postsocjalizmu, okres powojenny podzielono na dwa podokresy, obejmujące lata 1945-1989 i 1990-2018. Na drugim etapie badań skupiono się na identyfikacji głównych trendów zmian granic administracyjnych miast po $1989 \mathrm{r}$.

\section{ZMIANY ADMINISTRACYJNE MIAST W OKRESIE POWOJENNYM}

$\mathrm{W}$ okresie powojennym $\mathrm{w}$ Polsce miały miejsce bardzo intensywne procesy urbanizacji. W latach 1946-2017 liczba ludności miejskiej zwiększyła się z 7,6 mln do 23,1 mln, natomiast liczba miast wzrosła z 688 w 1945 r. do 930 w 2018 r. Wzrost liczby ludności miejskiej trwał nieprzerwanie aż do roku 1997, kiedy polskie miasta zamieszkiwało $23,9 \mathrm{mln}$ osób, a udział ludności miejskiej osiągnął 61,9\% (przy 31,8\% w 1946 r.). W ostatnich kilkunastu latach nastąpił z kolei nieznaczny spadek liczby ludności zamieszkującej w miastach (do poziomu 60,2\%, na co mają wpływ głównie procesy suburbanizacji). Zasadniczymi czynnikami wzrostu liczby ludności miejskiej w Polsce do 1997 r. były przyrost naturalny $(43,7 \%)$ i saldo migracji $(35,8 \%)$, podczas gdy zmiany administracyjne stanowiły $20,5 \%$ całkowitego przyrostu liczby ludności miejskiej (rys. 2) (por. Adamski, 2017; Szmytkie, 2014). Po 1997 r. zarówno przyrost naturalny, jak i saldo migracji w miastach było ujemne ${ }^{1}$, a jedynym czynnikiem wzrostu 
liczby ludności miejskiej były zmiany administracyjne miast.

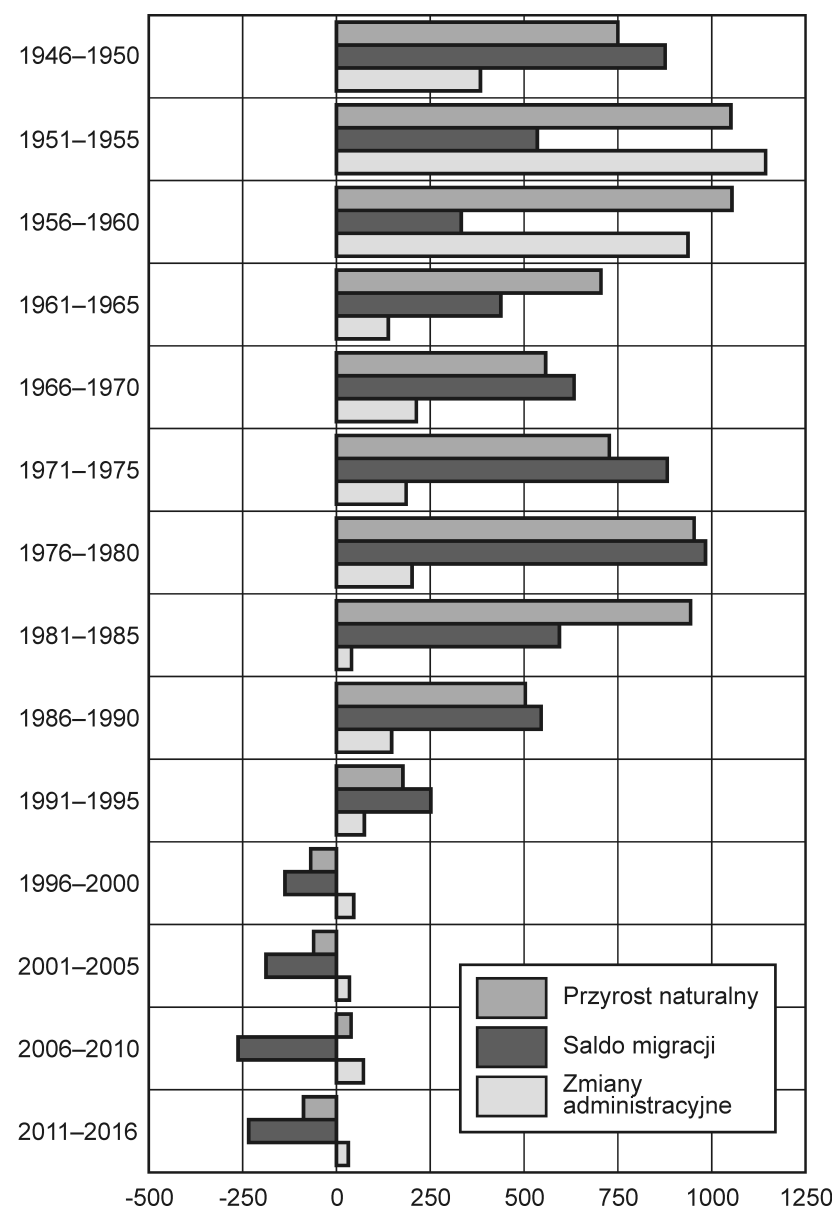

Rys. 2. Główne czynniki wzrostu ludności miejskiej w Polsce w latach 1946-2016

Źródło: opracowanie własne na podstawie: Rocznik statystyczny... (2017)

Okres powojenny cechował się zróżnicowaną dynamiką procesów inkorporacji i secesji, dzięki czemu można go podzielić na trzy podokresy różniące się nie tylko intensywnością, ale również charakterem zmian administracyjnych miast (rys. 3). W latach 1945-1972 dominowały procesy inkorporacji (samodzielność administracyjną w tym okresie utraciło 16 miast), choć były one dość sporadyczne. Największe nasilenie zmian administracyjnych miast miało miejsce w okresie „wielkich reform administracyjnych” w latach 1973-1977 (w 1973 r. nastąpiła likwidacja gromad i powołanie gmin zbiorowych, natomiast w 1975 r. doszło do utworzenia 49 województw w miejsce 17), co wynikało z konieczności dostosowania jednostek terytorialnych najniższego szczebla do nowych realiów podziału terytorialnego kraju. W omawianym okresie samodzielność administracyjną utraciło aż 45 miast, a jedna miejsco- wość odzyskała status miasta w wyniku secesji. Po 1977 r. intensywność zmian administracyjnych miast uległa wyraźnemu zmniejszeniu. Zmienił się także charakter zmian administracyjnych, bowiem obecnie przeważają procesy secesji, które nasiliły się zwłaszcza po wprowadzeniu ustawy samorządowej w 1990 r., zwiększającej uprawnienia społeczności lokalnych (Runge, 2005). W tym czasie samodzielność administracyjną odzyskało 12 miast (z których 9 w latach 1991-1998), a jedno było inkorporowane $\mathrm{w}$ granice innego miasta (Wesoła, wcielona w 2002 r. w granice Warszawy).

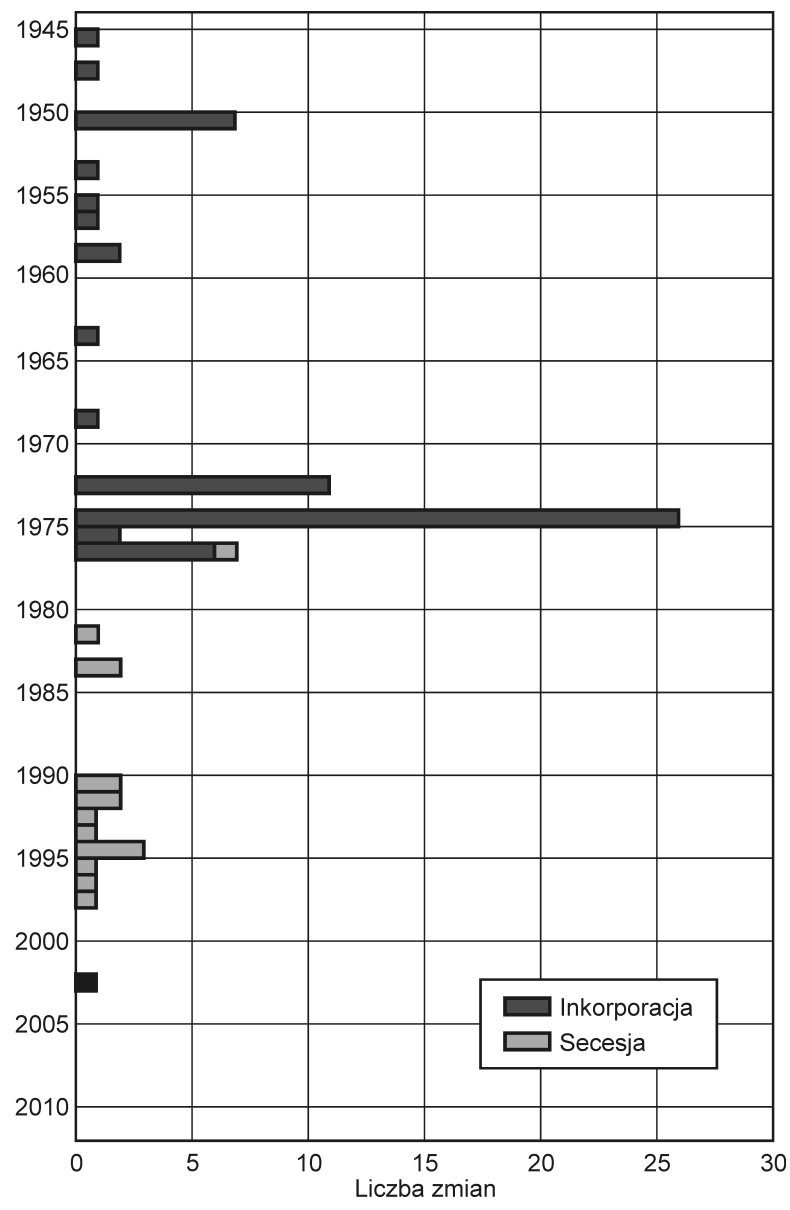

Rys. 3. Zmiany liczby miast $w$ Polsce $w$ okresie powojennym w wyniku procesów inkorporacji i secesji

Źródło: opracowanie własne na podstawie: Zmiany administracyjne... (1985); Powierzchnia i ludność... (1994-2018)

Procesom inkorporacji podlegały także osiedla miejskie, które w 1954 r. zostały wprowadzone do struktury osadniczej kraju (Szmytkie, 2003). W latach 1954-1963 utworzono 162 osiedla, z których 12 do końca 1972 r. utraciło samodzielność administracyjną (rys. 4). Kategoria osiedla miejskiego została zlikwidowana z początkiem 1973 r., a większość pozostałych osiedli została zdegradowana do rangi 
wsi lub uzyskała status miasta. Jednocześnie od 1973 r. aż 11 jednostek miejskich utraciło samodzielność administracyjną i zostało wcielonych $\mathrm{w}$ granice sąsiednich miast (Zmiany administracyjne..., 1985).

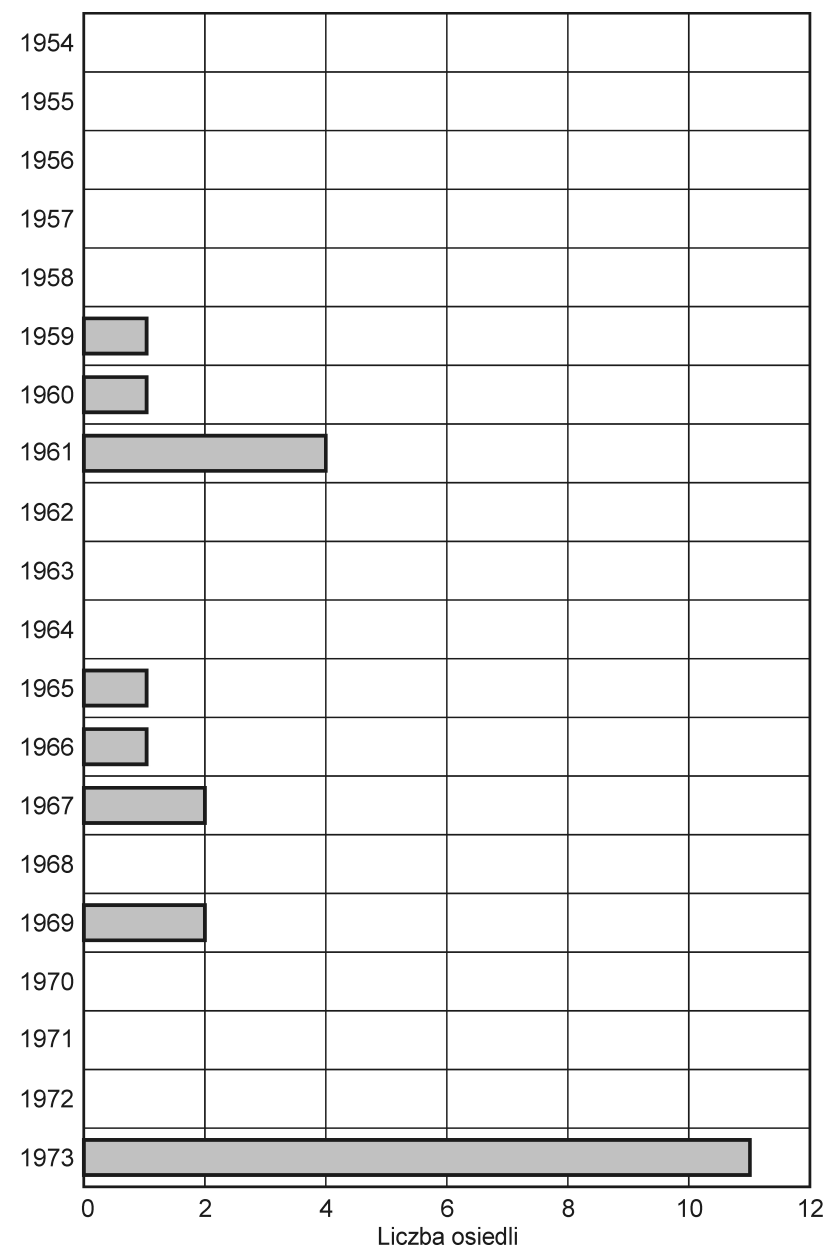

Rys. 4. Liczba osiedli, które utraciły samodzielność administracyjną w latach 1954-1973

Źródło: opracowanie własne na podstawie: Zmiany administracyjne... (1985)
Tab. 2. Miasta w Polsce w latach 1950-1989 z największym bezwzględnym wzrostem liczby ludności w wyniku zmian granic administracyjnych

\begin{tabular}{|l|c|c|c|}
\hline \multicolumn{1}{|c|}{ Miasto } & $\begin{array}{c}\text { Wojewódz- } \\
\text { two }\end{array}$ & $\begin{array}{c}\text { Bezwzględny } \\
\text { wzrost liczby } \\
\text { mieszkańców }\end{array}$ & $\begin{array}{c}\text { Liczba } \\
\text { ludności } \\
\text { w 1989 r. }\end{array}$ \\
\hline Warszawa & mazowieckie & 206700 & 1656468 \\
\hline Katowice & śląskie & 98957 & 367014 \\
\hline Bytom & śląskie & 97757 & 228306 \\
\hline Ruda Śląska & śląskie & 78349 & 167858 \\
\hline Wodzisław Śląski & śląskie & 66711 & 110040 \\
\hline Rybnik & śląskie & 60079 & 140308 \\
\hline Sosnowiec & śląskie & 51923 & 258635 \\
\hline Dąbrowa Górnicza & śląskie & 45380 & 136591 \\
\hline Tychy & śląskie & 44009 & 187489 \\
\hline Wałbrzych & dolnośląskie & 40090 & 141002 \\
\hline
\end{tabular}

Źródło: opracowanie własne na podstawie: Zmiany administracyjne... (1985), Powierzchnia i ludność... (1994-2018).

Analiza zmian liczby ludności wywołanych przez zmiany granic administracyjnych miast $\mathrm{w}$ odniesieniu do dwóch przyjętych podokresów wykazała znaczną różnicę w skali i intensywności zjawiska między okresem socjalizmu i postsocjalizmu. W latach 1945-1989 zmiany te miały dużą dynamikę, co przyczyniło się do znacznego zwiększenia liczby ludności w kilkudziesięciu miastach (w przypadku 48 miast wzrost ten wynosił od 5000 do 20000 osób, a w 26 ośrodkach przekraczał 20000 osób). Największy bezwzględny wzrost liczby ludności w wyni$\mathrm{ku}$ zmian granic administracyjnych odnotowano w miastach dużych, tzn. w Warszawie i największych miastach konurbacji katowickiej (tab. 2), dla których zmiany granic były niejako formalnym potwierdzeniem ich naturalnego rozwoju, polegającym na "wylewaniu się" miasta poza granice administracyjne i na wchłanianiu miejscowości (w tym

Tab. 3. Miasta w Polsce z największym względnym wzrostem liczby ludności w wyniku zmian granic administracyjnych w latach 1950-1989

\begin{tabular}{|l|c|c|c|c|}
\hline \multirow{2}{*}{ Miasto } & \multirow{2}{*}{ Województwo } & \multicolumn{2}{c|}{ Wzrost liczby mieszkańców } & \multirow{2}{*}{$\begin{array}{c}\text { Liczba ludności } \\
\text { w } 1989 \text { r. }\end{array}$} \\
\cline { 3 - 4 } & & względny (\%) & bezwzględny & 110040 \\
\hline Wodzisław Śląski & Śląskie & 60,6 & 66711 & 20589 \\
\hline Trzebinia & małopolskie & 57,6 & 11862 & 19614 \\
\hline Boguszów-Gorce & dolnośląskie & 57,0 & 11173 & 16211 \\
\hline Konstancin-Jeziorna & mazowieckie & 53,5 & 8670 & 18192 \\
\hline Orzesze & śląskie & 48,3 & 8788 & 29188 \\
\hline Czzerwionka-Leszczyny & śląskie & 47,4 & 13839 & 167858 \\
\hline Ruda Śląska & śląskie & 46,7 & 78349 & 25414 \\
\hline Pszczyna & Śląskie & 44,4 & 11283 & 60142 \\
\hline Świętochłowice & Śląskie & 44,4 & 26685 & 27549 \\
\hline Nowa Ruda & dolnośląskie & 43,9 & 12102 & \\
\hline
\end{tabular}

Źródło: opracowanie własne na podstawie: Zmiany administracyjne... (1985), Powierzchnia i ludność... (1994-2018). 


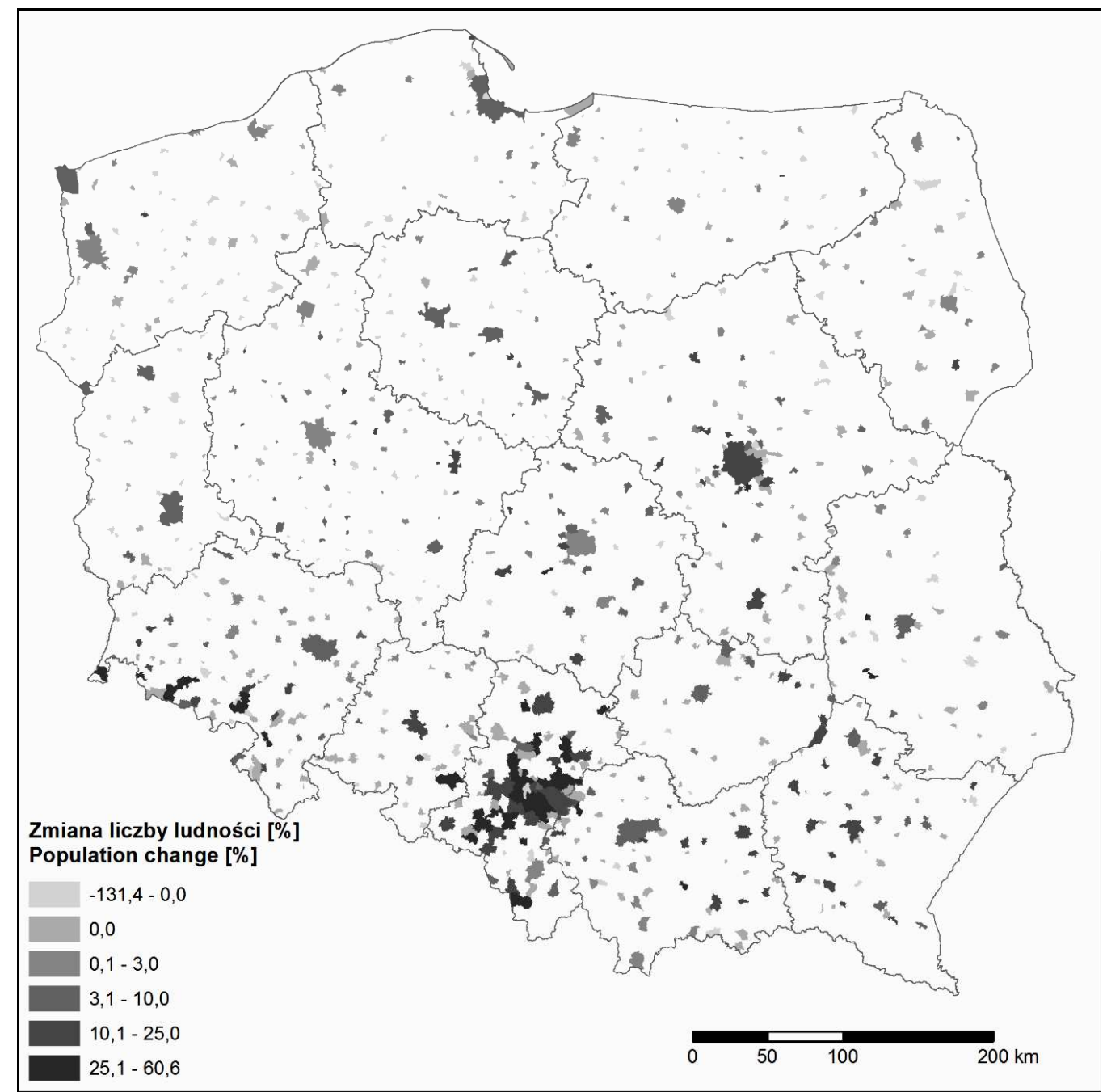

Rys. 5. Względne zmiany liczby ludności w miastach Polski w wyniku zmian granic administracyjnych w latach 1945-1989

Źródło: opracowanie własne na podstawie: Zmiany administracyjne... (1985); Powierzchnia i ludność... (1994-2018)

innych miast) położonych w ich sąsiedztwie. Zmianom tym podlegały również miasta małe i średniej wielkości (por. Jelonek, Zborowski, 1992; Szymańska, Grzelak-Kostulska, Hołowiecka, 2006, 2009), dla których był to jeden z głównych czynników wzrostu ludnościowego (tab. 3), zwłaszcza że w praktyce administracyjnej często łączone były miejscowości o podobnej wielkości i randze (Szmytkie, 2014). Dlatego w 23 miastach względny wzrost liczby ludności $\mathrm{w}$ wyniku zmian granic administracyjnych przekroczył nawet $30 \% \mathrm{w}$ stosunku do liczby mieszkańców w 1989 r. (rys. 5). Zmiany granic administracyjnych w latach 1945-1989 objęły 598 miast.

W okresie 1990-2017 r. zmiany granic administracyjnych dotyczyły 163 miast. Nie tylko spadła intensywność zmian granic administracyjnych (tab. 4), zmienił się też ich charakter. W większości przypadków procesy inkorporacji polegały na korektach granic administracyjnych, związanych z przyłączeniem terenów wcześniej faktycznie zajętych już przez miasto. We wspomnianym okresie (1990-2017) największy bezwzględny wzrost liczby ludności w wyniku zmian granic administracyjnych wystapił w miastach: Zielona Góra, Warszawa, Rzeszów i Opole (tab. 5). W Warszawie miał on związek z inkorporacją miasta Wesoła w 2002 r., natomiast w pozostałych ośrodkach $\mathrm{z}$ wcielaniem podmiejskich wsi. Po 1989 r. powszechne stały się też procesy dezintegracji miast-zlepieńców (miast sztucznie powiększonych w latach 70. XX w.). Najbardziej spektakularnie proces ten przebiegał w "Wielkich Tychach" i Wodzisławiu Śląskim (Szmytkie, 2005). Po roku 2004 były obserwowane również procesy dezintegracji tzw. zlepieńców miejsko-wiejskich (Szczawnica, Czarna Woda, Władysławowo, Pieszyce i Jastarnia), co było związane $z$ usamodzielnieniem się wsi 
funkcjonujących w ich granicach oraz zmianą statusu gminy (Szmytkie, 2016).

Tab. 4. Porównanie zmian granic administracyjnych miast w Polsce w latach 1945-1989 i 1990-2017

\begin{tabular}{|c|c|c|}
\hline \multirow{2}{*}{ Charakter zmiany } & \multicolumn{2}{|c|}{ Liczba miast w latach } \\
\cline { 2 - 3 } & $1945-1989$ & $1990-2017$ \\
\hline Wzrost liczby mieszkańców & $\mathbf{2 1 7}$ & 37 \\
\hline Powyżej 50 000 & 7 & 0 \\
\hline $20000-50000$ & 19 & 0 \\
\hline $5000-20000$ & 48 & 4 \\
\hline $2000-5000$ & 52 & 8 \\
\hline $500-2000$ & 91 & 25 \\
\hline Spadek liczby mieszkańców & 51 & $\mathbf{1 4}$ \\
\hline $500-2000$ & 48 & 5 \\
\hline $2000-5000$ & 3 & 1 \\
\hline $5000-20000$ & 0 & 6 \\
\hline Powyżej 20 000 & 0 & 2 \\
\hline
\end{tabular}

Źródło: opracowanie własne na podstawie: Zmiany administracyjne... (1985); Powierzchnia i ludność... (1994-2018).

Tab. 5. Miasta w Polsce z największym bezwzględnym wzrostem liczby ludności w wyniku zmian granic administracyjnych w latach 1990-2017

\begin{tabular}{|l|c|c|c|}
\hline \multicolumn{1}{|c|}{ Miasto } & Województwo & $\begin{array}{c}\text { Wzrost } \\
\text { liczby } \\
\text { mieszkańców }\end{array}$ & $\begin{array}{c}\text { Liczba } \\
\text { ludności } \\
\text { w 2017 r. }\end{array}$ \\
\hline Zielona Góra & lubuskie & 19592 & 139330 \\
\hline Warszawa & mazowieckie & 19148 & 1753977 \\
\hline Rzeszów & podkarpackie & 18753 & 188021 \\
\hline Opole & opolskie & 9321 & 128043 \\
\hline Białystok & podlaskie & 3683 & 296628 \\
\hline
\end{tabular}

Źródło: opracowanie własne na podstawie Powierzchnia i ludność... (1994-2018).

Mimo istotnego zmniejszenia się intensywności zmian granic administracyjnych miast po 1989 r., zmiany podziału terytorialnego na szczeblu lokalnym w dalszym ciągu występują dość powszechnie. Dotyczy to zwłaszcza liczebności, granic oraz statusu formalnoprawnego jednostek terytorialnych (Kaczmarek, 2016). Według Kaczmarka (2016) wynikało to z kilku przyczyn:

1) odziedziczony po okresie socjalizmu podział terytorialny nie był do końca akceptowany, bowiem odpowiadał on realiom zcentralizowanego i resortowo zarządzanego państwa;

2) niektóre gminy w swych rozmiarach przestrzennych nie odpowiadały zapisom Ustawy o samorzadzie gminnym (1990 r.), gdzie jednostki lokalne powinny być „możliwie jednorodne ze względu na układ osadniczy i przestrzenny, uwzględniający więzi społeczne, gospodarcze i kulturowe oraz zapewniający zdolność wykonywania zadań publicznych";
3) rozwój trzeciego sektora gospodarki, wykształcenie się wielu nowych funkcji publicznych powodowały wzrost zadań administracji terytorialnej, także na poziomie lokalnym;

4) rozwój samorządności przyczynił się do rozwoju świadomości lokalnej - potrzeba samostanowienia leżała $\mathrm{u}$ źródeł zmian struktur gminnych, jednocześnie przywiązanie do tradycji i chęć niezależności były przyczyną niechęci do zmian granic gminnych.

\section{ROZPAD MIAST-ZLEPIEŃCÓW}

Nasilone procesy inkorporacji, które miały miejsce w latach 1973-1977, przyczyniły się do powstania miast o niespójnych strukturach przestrzennych, będących faktycznie zlepkiem kilku samodzielnych jednostek osadniczych. Co więcej, miasta-zlepieńce powstawały $\mathrm{w}$ wyniku odgórnych decyzji politycznych, niezależnie od kierunków rozwoju przestrzennego miasta oraz bez akceptacji społeczności lokalnych (Szmytkie, 2009). Dodatkowo peryferyjne położenie w granicach „wielkiego miasta”, nierówny podział środków między dzielnicami, brak znaczących związków funkcjonalno-przestrzennych i więzi kulturowych, niedorozwój infrastruktury oraz demobilizacja społeczności lokalnych potęgowały poczucie odrębności i odmienności, a także niezadowolenie wśród mieszkańców inkorporowanych miejscowości (Jarczewski, 2002; Szczepański, 1991, 1996; Szmytkie, 2005, 2009). Czynniki te inicjowały dążenia secesyjne, związane z chęcią odzyskania samodzielności administracyjnej, jak również utraconych w wyniku inkorporacji praw miejskich (Runge, 2005). Dotyczyło to zwłaszcza ośrodków posiadających silne zaplecze gospodarcze lub liczących na pozyskanie nowych źródeł dochodów po secesji (Jarczewski, 2002). O tym, że zmiany granic administracyjnych miast $w$ okresie wielkich reform podziału terytorialnego $\mathrm{w}$ latach 1973-1977 były dokonywane na wyrost, świadczy chociażby fakt, że pierwsze procesy secesji miały miejsce już w latach 70. i 80. XX w., czyli zaledwie kilka lub kilkanaście lat po inkorporacji. W tym czasie samodzielność administracyjną odzyskały miasta: Zagórz (1977 r.), Poręba (1982 r.) oraz Międzyzdroje i Sławków (1984 r.). W 1982 r. doszło też do podziału miasta Szczawnica-Krościenko (Szmytkie, 2005, 2014).

Procesy secesji w Polsce nasiliły się po 1990 r., co było związane z przywróceniem samorządności lokalnej wraz z Ustawa o samorzadzie gminnym. Jako 
pierwsze rozpadło się w 1991 r. miasto „Wielkie Tychy". W kolejnych latach procesy dezintegracji dotyczyły również miast: Wodzisław Śląski, Będzin (w 1991 r. samodzielność odzyskały Wojkowice), Mysłowice (Imielin w 1994 r.), Tarnowskie Góry (Miasteczko Śląskie w 1994 r.) i Bytom (Radzionków w 1997 r.) (Szmytkie, 2005). W latach 1991-1998 samodzielność administracyjną $\mathrm{w}$ regionie śląskim odzyskało w sumie 13 gmin, w tym 9 gmin miejskich (Jarczewski, 2002). W większości przypadków secesja przyczyniła się do częściowego rozpadu miast-zlepieńców powstałych w latach 70. XX w. Na tym tle wyróżniają się miasta "Wielkie Tychy" i Wodzisław Śląski, w przypadku których doszło do wydzielenia wszystkich jednostek, które nie stały się integralnymi osiedlami miasta, a zatem do całkowitego rozpadu zlepieńca. W przypadku „Wielkich Tychów" rozpad miasta nastąpił na jednym etapie, a w przypadku Wodzisławia Śląskiego odbywał się stopniowo, na kilku etapach (Szmytkie, 2005, 2014).

Rozwój Tychów został zapoczątkowany w latach 50. XX w. wraz z decyzją Prezydium Rządu (uchwała o rozbudowie Tychów do miasta liczącego ponad 100 tys. mieszkańców, które miało pełnić funkcję miasta-sypialni dla Górnośląskiego Okręgu Przemysłowego) (Spórna, 2012). Przyczyniło się to zarazem do rozwoju terytorialnego miasta, którego powierzchnia wzrosła z 30,1 do $83,5 \mathrm{~km}^{2}$ w $1973 \mathrm{r}$. Największe zmiany terytorialne miały miejsce w latach 1975-1977, kiedy do Tychów wcielono miasta: Bierun Stary, Lędziny i Imielin², oraz gminy: Bierun Stary, Imielin, Wyry, Bojszowy i Kobiór (rys. 6). $\mathrm{W}$ wyniku tych zmian powierzchnia miasta wzrosła do $271 \mathrm{~km}^{2}$, a liczba ludności do 154,1 tys. osób w 1978 r. Miasto w tym kształcie przetrwało zaledwie kilkanaście lat, bowiem w 1990 r. została podjeta decyzja o podziale „Wielkich Tychów”. W wyniku presji społeczności przyłączonych w latach 70. XX w. do Tychów miejscowości w $1991 \mathrm{r}$. samodzielność administracyjną odzyskały miasta: Bieruń i Lędziny, a także gminy wiejskie: Bojszowy, Kobiór i Wyry (Szczepański, 1996). Zmiany te spowodowały, że obszar miasta zmniejszył się do $81,8 \mathrm{~km}^{2}$, a liczba ludności o 52,9 tys. osób, podczas gdy gęstość zaludnienia wzrosła do 1699 osób na $1 \mathrm{~km}^{2}$ (tab. 6).

Intensywny rozwój terytorialny Wodzisławia Śląskiego miał miejsce w latach 70. XX w. W 1973 r. wcielono do miasta gromadę Wilchwy oraz wsie Marusze i Turzyczka, w 1975 r. miasta: Rydułtowy, Pszów i Radlin oraz gminę Marklowice, a w 1983 r. obręby geodezyjne: Mszana i Czyżowice. W wyniku

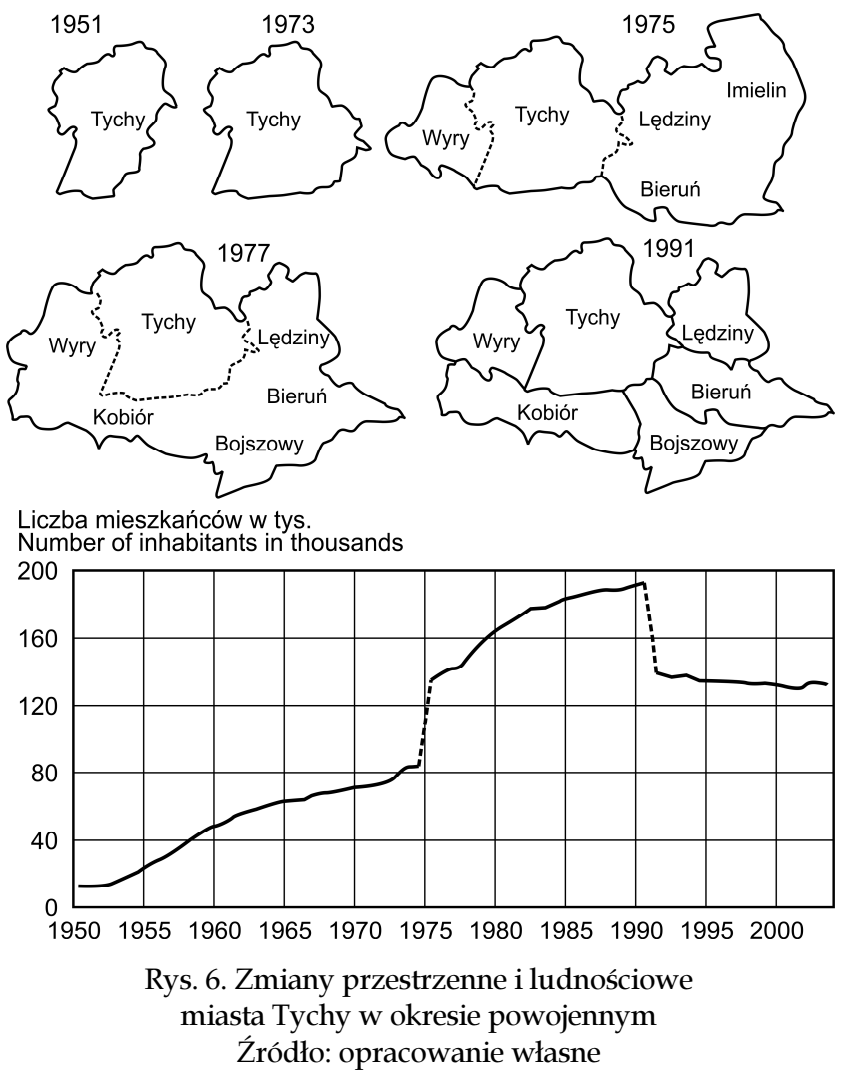

Tab. 6. Jednostki powstałe z rozpadu „Wielkich Tychów” w $1991 \mathrm{r}$.

\begin{tabular}{|l|c|c|c|}
\hline \multicolumn{1}{|c|}{ Jednostka } & $\begin{array}{c}\text { Powierzchnia } \\
\left(\mathrm{km}^{2}\right)\end{array}$ & $\begin{array}{c}\text { Liczba } \\
\text { ludności }\end{array}$ & $\begin{array}{c}\text { Gęstość } \\
\text { zaludnienia } \\
(\text { osób/1 km²) }\end{array}$ \\
\hline Miasto Bieruń & 40,19 & 21200 & 527,5 \\
\hline Miasto Lędziny & 31,04 & 16200 & 521,9 \\
\hline Gmina Bojszowy & 34,07 & 5500 & 161,4 \\
\hline Gmina Kobiór & 49,50 & 4000 & 80,8 \\
\hline Gmina Wyry & 34,45 & 6000 & 174,2 \\
\hline Razem & 189,25 & 52900 & 279,5 \\
\hline
\end{tabular}

Źródło: opracowanie własne na podstawie: Powierzchnia i ludność... (1994).

tych zmian powierzchnia miasta wzrosła z 27,0 do $111,1 \mathrm{~km}^{2}$, a liczba ludności zwiększyła się z 34,7 tys. w 1974 r. do 101,9 tys. w 1975 r. (rys. 7). Rozpad Wodzisławia Śląskiego rozpoczął się w roku 1992, kiedy z jego granic wydzielono miasto Rydułtowy (liczące 23900 mieszkańców). W kolejnych latach samodzielność administracyjną odzyskały: gmina Marklowice - w 1994 r. (5099 osób), miasto Pszów - w 1995 (14 934 ludności) i miasto Radlin - w 1997 (18 222 mieszkańców). W efekcie obszar Wodzisławia Śląskiego zmniejszył się do $49,5 \mathrm{~km}^{2}$, a liczba mieszkańców do 49,7 tys. W roku 2008 Wodzisław Śląski liczył 49406 ludności, a w jednostkach tworzących do 1992 r. miasto, zamieszkiwało 107869 osób (tab. 7). 


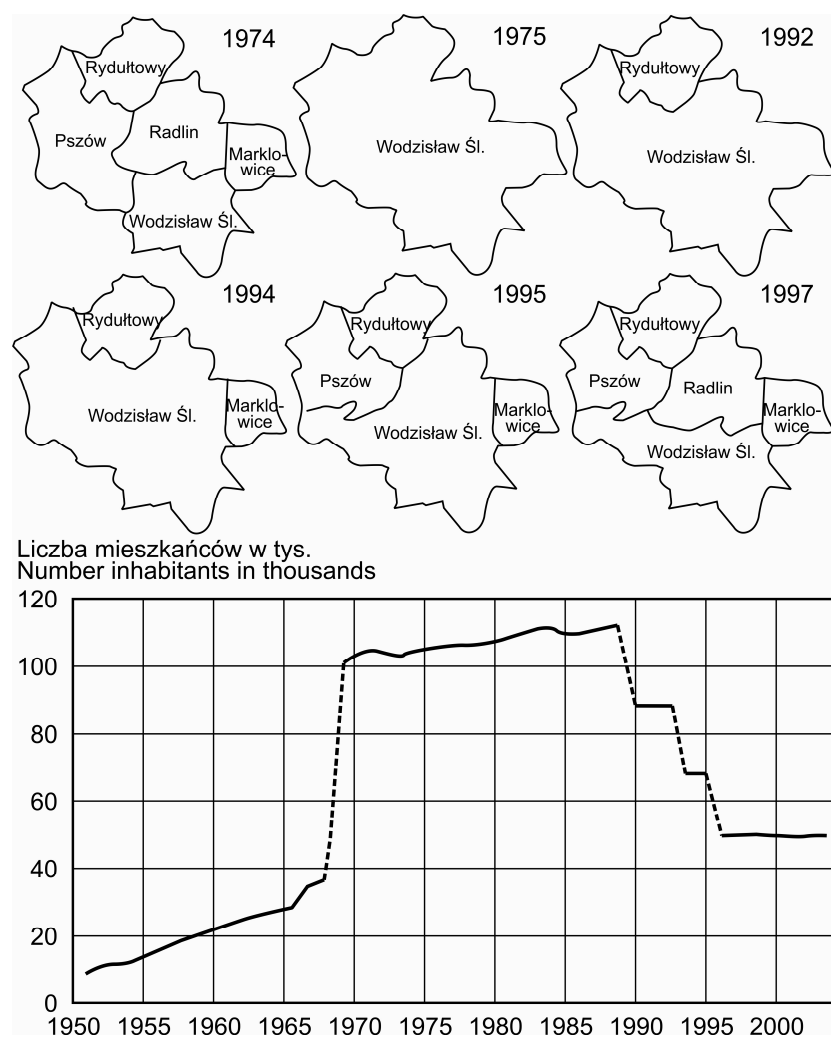

Rys. 7. Zmiany przestrzenne i ludnościowe miasta Wodzisław Śląski

Źródło: opracowanie własne

Tab. 7. Jednostki tworzące niegdyś (1975-1991) Wodzisław Śląski - dane za 2016 r.

\begin{tabular}{|l|c|c|c|}
\hline \multicolumn{1}{|c|}{ Jednostka } & $\begin{array}{c}\text { Powie- } \\
\text { rzchnia } \\
\left(\mathrm{km}^{2}\right)\end{array}$ & $\begin{array}{c}\text { Liczba } \\
\text { ludności }\end{array}$ & $\begin{array}{c}\text { Gęstość } \\
\text { zludnienia } \\
(\text { osób/1 km²) }\end{array}$ \\
\hline Miasto Wodzisław Śl. & 49,51 & 48573 & 981 \\
\hline Miasto Pszów & 20,44 & 14186 & 694 \\
\hline Miasto Radlin & 12,53 & 17784 & 1426 \\
\hline Miasto Rydułtowy & 14,95 & 21715 & 1453 \\
\hline Gmina Marklowice & 13,69 & 5403 & 395 \\
\hline Razem & 111,12 & 107661 & 969 \\
\hline
\end{tabular}

Źródło: opracowanie własne na podstawie: Powierzchnia i ludność... (2009).

\section{ROZPAD ZLEPIEŃCÓW MIEJSKO-WIEJSKICH}

Problem dezintegracji terytorialnej dotyczył też tzw. zlepieńców miejsko-wiejskich (Szmytkie, 2005/6, 2009). Ich specyfika wyraża się $\mathrm{w}$ dwudzielności struktur przestrzennych. W miastach tych można wyróżnić część faktycznie miejską (właściwe miasto) i część wiejską, która obejmuje jednostki o wiejskim charakterze, będące dawnymi wsiami wcielonymi $\mathrm{w}$ granice miasta. Mimo upływu czasu od utraty samodzielności administracyjnej zachowały one swój pierwotny wiejski charakter, co dotyczy w szczególności zabudowy i rozplanowania, a także pełnionych funkcji. Zlepieńce miejsko-wiejskie były tworzone głównie na obszarach marginalnych dla osadnictwa: w górach (Szmytkie, 2005/6), na obrzeżach dużych kompleksów leśnych i na wybrzeżu. Miasta te cechują się dużą powierzchnią (przy stosunkowo małej liczbie ludności), niską w porównaniu do innych miast gęstością zaludnienia oraz wysokim wskaźnikiem lesistości (lub dużym udziałem użytków rolnych).

Szmytkie (2005/6), próbując określić przyszłość administracyjną trzech zlepieńców miejsko-wiejskich położonych na obszarze Sudetów (Kudowa Zdrój, Piechowice i Pieszyce), stwierdził, że mogą one przekształcić się z gmin miejskich w miejsko-wiejskie, za czym przemawiają następujące czynniki:

1) brak spójności przestrzennej, niedostatecznie działająca komunikacja w obrębie miasta i słabe związki funkcjonalno-przestrzenne między poszczególnymi osiedlami;

2) odrębność jednostek tworzących miasto w obecnych granicach, wynikająca $\mathrm{z}$ charakteru funkcjonalno-przestrzennego czy poczucia odrębności mieszkańców, co ma potwierdzenie m.in. w powszechnym użyciu nazw miejscowych;

3) wiejski charakter przyłączonych do miasta miejscowości, znajdujący odzwierciedlenie w wiejskim charakterze zabudowy, typowym dla wsi rozplanowaniu, wiejskim stylu życia mieszkańców oraz w sferze funkcjonalnej;

4) duże dysproporcje między miastem a jego "częścią niemiejską", zwłaszcza jeśli chodzi o charakter zabudowy, potencjał gospodarczy i pełnione funkcje;

5) korzyści finansowe dla mieszkańców i władz lokalnych związane $\mathrm{z}$ dotacjami unijnymi dla obszarów wiejskich (na rozwój rolnictwa, agroturystyki czy przedsiębiorczości).

Podobne przesłanki wskazywane były też w uzasadnieniach do rozporządzeń Rady Ministrów $\mathrm{w}$ sprawie zmiany statusu analizowanych gmin miejskich i ustalenia granic miast. W sytuacji zmiany statusu gminy z miejskiej na miejsko-wiejską procedura administracyjna wymaga $w$ pierwszej kolejności odebrania statusu miasta wnioskującej gminie miejskiej, a następnie nadania statusu miasta i określenia (zawężenia) jego granic (poprzez wydzielenie $\mathrm{z}$ jego terytorium jednostek o wiejskim charakterze). W ten sposób dochodzi do podziału gminy na dwie części: miejską (miasto) i wiejską (sołectwa powstałe z osiedli wyłączonych z granic miasta). 
W latach 2008-2016 doszło do zmiany statusu pięciu gmin miejskich na gminy miejsko-wiejskie (Szczawnica - w 2008 r., Czarna Woda - 2014, Władysławowo - 2015, Pieszyce - 2016 r. i Jastarnia - 2017), co wiązało się z wyłączeniem z granic administracyjnych wymienionych miast 17 solectw (tab. 8) i z podziałem dotychczasowych gmin miejskich na dwie części - miejską i wiejską (tab. 9).

Tab. 8. Sołectwa wyodrębnione $\mathrm{w}$ wyniku zmiany statusu gmin w Polsce w latach 2008-2017

\begin{tabular}{|l|l|c|c|}
\hline \multicolumn{1}{|c|}{ Sołectwo } & \multicolumn{1}{|c|}{ Gmina } & $\begin{array}{c}\text { Rok } \\
\text { powstania }\end{array}$ & $\begin{array}{c}\text { Liczba } \\
\text { ludności }\end{array}$ \\
\hline Bratoszów & Pieszyce & 2016 & 217 \\
\hline Chałupy & Władysławowo & 2015 & 376 \\
\hline Chłapowo & Władysławowo & 2015 & 1069 \\
\hline Huta Kalna & Czarna Woda & 2014 & 168 \\
\hline Jastrzębia Góra & Władysławowo & 2015 & 1068 \\
\hline Jaworki & Szczawnica & 2008 & 568 \\
\hline Jurata & Jastarnia & 2017 & 512 \\
\hline Kamionki & Pieszyce & 2016 & 557 \\
\hline Karwia & Władysławowo & 2015 & 931 \\
\hline Kuźnica & Jastarnia & 2017 & 617 \\
\hline Lubiki & Czarna Woda & 2014 & $250^{\mathrm{b}}$ \\
\hline Ostrowo & Władysławowo & 2015 & 605 \\
\hline Piskorzów & Pieszyce & 2016 & 588 \\
\hline Rościszów & Pieszyce & 2016 & 727 \\
\hline Rozewie & Władysławowo & 2015 & 323 \\
\hline Szlachtowa & Szczawnica & 2008 & 880 \\
\hline Tupadły & Władysławowo & 2015 & 439 \\
\hline
\end{tabular}

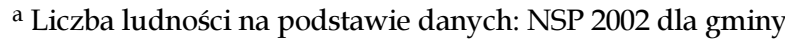
Czarna Woda, NSP 2011 dla miasta Szczawnica, Urzędu Miasta w Pieszycach z 2004 r., Urzędu Miasta we Władysławowie z 2012 r. oraz Urzędu Miasta w Jastarni z 2013 r.

b W tym miejscowości: Lubiki - 154 mieszkańców, Lubiki Małe - 96 osób.

Źródło: opracowanie własne.
W uzasadnieniach do rozporządzeń, w sprawie zmian statusu gmin miejskich i ustalenia granic miast, we wszystkich analizowanych przypadkach pojawily się podobne stwierdzenia dotyczące uwarunkowań przestrzenno-infrastrukturalnych i społecznych, przemawiających za pozytywnym rozpatrzeniem wniosków (Szmytkie, 2016): dominacja funkcji rolniczych i turystycznych na terenach proponowanych do wyłączenia $\mathrm{z}$ granic administracyjnych miasta;

a) posiadanie jednorodnego układu osadniczego i przestrzennego;

b) brak podstawowej infrastruktury komunalnej (kanalizacja, wodociąg);

c) stopień urbanizacji odbiegający od pozostałej części miasta;

d) możliwość skorzystania ze środków unijnych przeznaczonych dla obszarów wiejskich;

e) możliwość rozwoju agroturystyki;

f) pozytywne wyniki konsultacji.

Nieco bardziej złożona sytuacja miała miejsce w przypadku Pszczyny. W 1975 r. do miasta przyłączono gminy Goczałkowice-Zdrój i Wisła Wielka, co spowodowało wzrost liczby mieszkańców o 15828 osób. W 1977 r. z granic miasta wyłączono sołectwa: Studzionka, Wisła Mała i Wisła Wielka (w sumie 4545 mieszkańców), które przyłączono do gminy Pszczyna. W 1992 r. samodzielność administracyjną odzyskały Goczałkowice-Zdrój (5947 osób), stając się odrębną gminą wiejską. W 1998 r. od miasta odłączono natomiast wszystkie pozostałe z przyłączonych w 1975 r. solectwa: Brzeźce, Ćwiklice, Łąka, Poręba i Rudołtowice (w sumie 8048 osób), które stały się odrębnymi wsiami w gminie Pszczyna.

Tab. 9. Podstawowe informacje na temat gmin miejskich przekształconych w gminy miejsko-wiejskie w latach 2008-2017

\begin{tabular}{|c|c|c|c|c|c|c|c|c|c|}
\hline \multirow{3}{*}{ Gmina } & \multirow{2}{*}{\multicolumn{3}{|c|}{ Przed zmianą }} & \multicolumn{6}{|c|}{ Po zmianie } \\
\hline & & & & \multicolumn{3}{|c|}{ część miejska } & \multicolumn{3}{|c|}{ część wiejska } \\
\hline & $\begin{array}{l}\text { powie- } \\
\text { rzchnia }\end{array}$ & $\begin{array}{c}\text { liczba } \\
\text { ludności }\end{array}$ & $\begin{array}{l}\text { gęstość } \\
\text { zalud- } \\
\text { nienia }\end{array}$ & $\begin{array}{l}\text { powie- } \\
\text { rzchnia }\end{array}$ & $\begin{array}{l}\text { liczba } \\
\text { ludności }\end{array}$ & $\begin{array}{l}\text { gęstość } \\
\text { zalud- } \\
\text { nienia }\end{array}$ & $\begin{array}{l}\text { powie- } \\
\text { rzchnia }\end{array}$ & $\begin{array}{c}\text { liczba } \\
\text { ludności }\end{array}$ & $\begin{array}{l}\text { gęstość } \\
\text { zalud- } \\
\text { nienia }\end{array}$ \\
\hline Czarna Woda & 27,73 & 3284 & 118,4 & 9,94 & 2863 & 288,0 & 17,79 & 421 & 23,7 \\
\hline Jastarnia & 7,80 & 3782 & 484,9 & 4,31 & 2734 & 634,3 & 3,49 & 1048 & 300,3 \\
\hline Pieszyce & 63,61 & 9586 & 150,7 & 17,72 & 7497 & 423,1 & 45,89 & 2089 & 45,5 \\
\hline Szczawnica & 87,90 & 7372 & 83,9 & 32,90 & 6032 & 183,3 & 55,00 & 1340 & 24,4 \\
\hline Władysławowo & 39,22 & 15456 & 394,1 & 12,59 & 10053 & 798,5 & 26,63 & 5403 & 202,9 \\
\hline
\end{tabular}

Objaśnienia: powierzchnia - w km²; gęstość zaludnienia - liczba osób/1km²).

Źródło: opracowanie własne na podstawie: Powierzchnia i ludność... (2009-2015). 


\section{INKORPORACJA MIEJSCOWOŚCI PODMIEJSKICH}

Po 1989 r. procesy inkorporacji straciły na intensywności, do czego w znacznym stopniu przyczynił się rozwój samorządności (zapoczątkowany wprowadzeniem Ustawy o samorządzie gminnym w roku 1990) i związany z nim rozwój świadomości lokalnej. Przyczyną niechęci do zmian granic administracyjnych są obecnie przywiązanie do tradycji i chęć niezależności (Kaczmarek, 2016). Dlatego też obserwowane w analizowanym okresie procesy inkorporacji mają w większości przypadków charakter nieznacznych korekt zmian granic administracyjnych, polegających na przyłączeniu do miasta terenów już faktycznie miejskich. Największy przyrost liczby ludności w wyniku zmian granic administracyjnych w latach 1990-2017 miał miejsce w Warszawie (w 2002 r. w jej granice wcielono miasto Wesoła) oraz w Zielonej Górze, Rzeszowie i Opolu, do których zostały przyłączone podmiejskie wsie. Intensywny rozwój terytorialny Rzeszowa odbywał się na kilku etapach, natomiast w przypadku Opola i Zielonej Góry na jednym etapie.

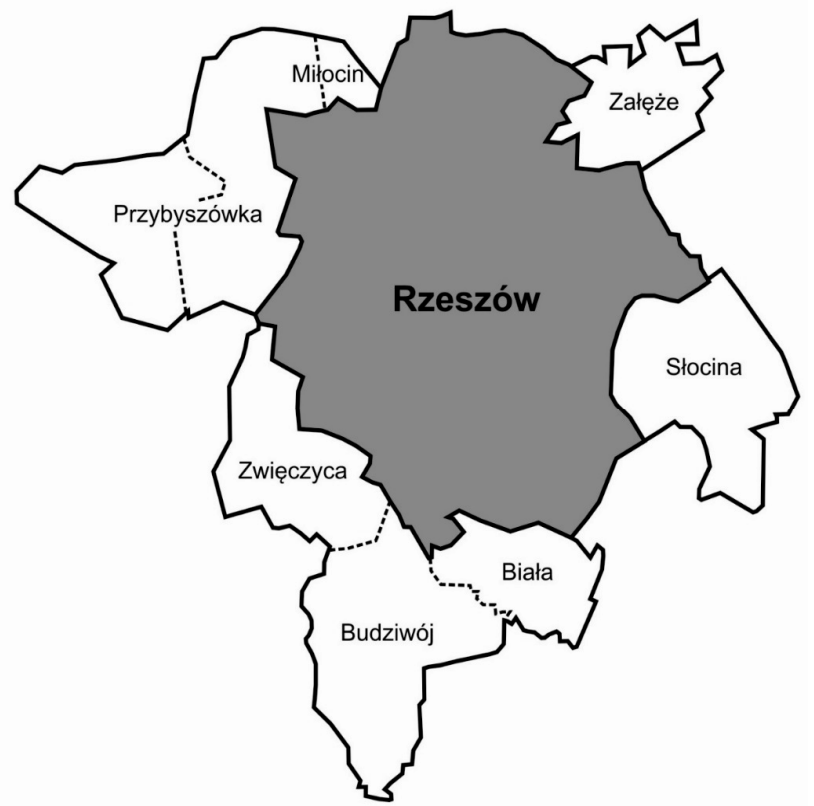

Rys. 8. Miejscowości wcielone do Rzeszowa w latach 2006-2017 Źródło: opracowanie własne

W 2005 r. Rzeszów liczył 158,5 tys. mieszkańców, zajmując powierzchnię $53,7 \mathrm{~km}^{2}$ (gęstość zaludnienia wynosiła 2952 osób/ $\mathrm{km}^{2}$ ). Z uwagi na brak powierzchni pod inwestycje, wskazywany od wielu lat przez urbanistów, wykraczanie granic funkcjonalnych miasta poza jego granice admini- stracyjne i dużą gęstość zaludnienia władze Rzeszowa podjęły decyzję o rozpoczęciu procedury przyłączenia okolicznych miejscowości wiejskich (Krzaklewski, 2008). Rozwój terytorialny Rzeszowa został zapoczątkowany w roku 2006 (Sikora, Hrehorowicz-Gaber, 2017), kiedy do miasta wcielono sołectwa Słociny i Załęże z gminy Krasne. W kolejnych latach do Rzeszowa przyłączono: część sołectwa Przybyszówka z gminy Świlcza w 2007 r., pozostałą część sołectwa Przybyszówka i sołectwo Zwięczyca z gminy Boguchwała w 2008 r., sołectwo Biała z gminy Tyczyn w 2009 r., sołectwo Budziwój z gminy Tyczyn i część sołectwa Miłocin z gminy Głogów Małopolski w 2010 r., a także sołectwo Bzianka z gminy Świlcza w 2017 r. Spowodowało to powiększenie powierzchni miasta do $120,4 \mathrm{~km}^{2}$ oraz wzrost liczby ludności o 18753 osoby (rys. 8, tab. 10). Z początkiem 2019 r. w granice Rzeszowa została wcielona pozostała część sołectwa Miłocin i sołectwo Matysówka z gminy Tyczyn.

Tab. 10. Miejscowości przyłączone do Rzeszowa w latach 2006-2017

\begin{tabular}{|l|l|c|c|}
\hline Rok & \multicolumn{1}{|c|}{ Miejscowość } & $\begin{array}{c}\text { Powierzchnia } \\
\left(\mathrm{km}^{2}\right)\end{array}$ & $\begin{array}{c}\text { Liczba } \\
\text { ludności }\end{array}$ \\
\hline \multirow{2}{*}{2006} & $\begin{array}{l}\text { Słocina } \\
\text { Załęże }\end{array}$ & 14,36 & 4530 \\
\hline 2007 & Przybyszówka (część) & 9,25 & 2070 \\
\hline \multirow{2}{*}{2008} & Przybyszówka (część) & 7,00 & 1429 \\
& Zwięczyca & 7,23 & 3344 \\
\hline 2009 & Biała & 6,06 & 2030 \\
\hline \multirow{2}{*}{2010} & Budziwój & 17,50 & 4074 \\
& Miłocin (część) & 1,24 & 677 \\
\hline 2017 & Bzianka & 4,05 & 599 \\
\hline
\end{tabular}

Źródło: opracowanie własne na podstawie Powierzchnia i ludność... (2006-2017) i uzasadnień do rozporządzeń Rady Ministrów.

W poszczególnych uzasadnieniach do rozporządzeń Rady Ministrów wskazywano następujące uwarunkowania i argumenty przemawiające za przedmiotowymi zmianami:

1) występowanie silnych powiązań komunikacyjnych oraz powiązań w zakresie infrastruktury społecznej i technicznej z miastem;

2) wskazanie barier przestrzennych rozwoju miasta i potrzeby powiększenia jego powierzchni w dokumentach strategicznych i planistycznych;

3) możliwość prowadzenia skoordynowanej polityki rozwoju przestrzennego miasta;

4) brak możliwości rozwojowych Rzeszowa w jego obecnych granicach administracyjnych, na co wpływa bardzo wysoka gęstość zaludnienia 
i najmniejsza powierzchnia spośród miast wojewódzkich;

5) pozyskanie nowych terenów pod budownictwo mieszkaniowe, inwestycje przemysłowe i usługi komercyjne;

6) niedostosowanie obecnych granic administracyjnych Rzeszowa do pełnionych przez niego funkcji (stolica województwa, gospodarcze, naukowe i kulturalne centrum Polski południowo-wschodniej) i utrudniają przekształcenie się miasta w dużą, nowoczesną metropolię.

Co więcej, miejscowości wcielone do Rzeszowa traciły samodzielność administracyjną mimo wyraźnego sprzeciwu ich mieszkańców, na co wskazują m.in. wyniki przeprowadzonych konsultacji społecznych (przeciwko przedmiotowym zmianom było m.in.: 93\% mieszkańców Zwięczycy, 81\% - Przybyszówki, 80\% - Słociny, 78\% - Załęża, 69\% - Miłocina i 53\% mieszkańców Matysówki).

W 2015 r. w granice miasta Zielona Góra wcielono obszar gminy wiejskiej Zielona Góra (powierzchnia 219,98 km², liczba ludności 19 592), co spowodowało wzrost powierzchni miasta do $278,32 \mathrm{~km}^{2}$ (dzięki czemu Zielona Góra stała się 6. miastem pod względem powierzchni w Polsce), wzrost liczby mieszkańców do 138,5 tys. osób i spadek gęstości zaludnienia z 2030 do 498 osób na 1 km². Jednocześnie została utworzona dzielnica Nowe Miasto, obejmująca obszar dawnej gminy wiejskiej, a miejscowości wchodzące $w$ jej skład zachowały status sołectw (rys. 9). We wniosku jako główne korzyści przemawiające za proponowaną zmianą wskazano: tzw. bonus ministerialny w wysokości $100 \mathrm{mln}$ zl, uniknięcie dwukrotnego przeprowadzenia w krótkim czasie wyborów samorządowych oraz możliwość ubiegania się o środki w nowej perspektywie finansowej UE. Perspektywa "bonusu materialnego" dla "nowego" miasta miała istotny wpływ na pozytywną opinię Rady Gminy Zielona Góra i wynik konsultacji społecznych na jej terenie, w których 52,7\% mieszkańców poparło likwidację gminy, a $45,9 \%$ osób było jej przeciwnych. Za inkorporacją opowiedzieli się $\mathrm{W}$ szczególności mieszkańcy wsi bezpośrednio graniczących z miastem (Stary i Nowy Kisielin), przeciwni połączeniu byli z kolei mieszkańcy miejscowości oddalonych od miasta. Obietnice złożone mieszkańcom dawnej gminy wiejskiej przez prezydenta miasta nie zostały jednak spełnione, co spowodowało niezadowolenie społeczne i poczucie wykorzystania (por. Jęczmionka, Koziołek, 2015; Kalinowski, 2018; Stawiarz, 2013).

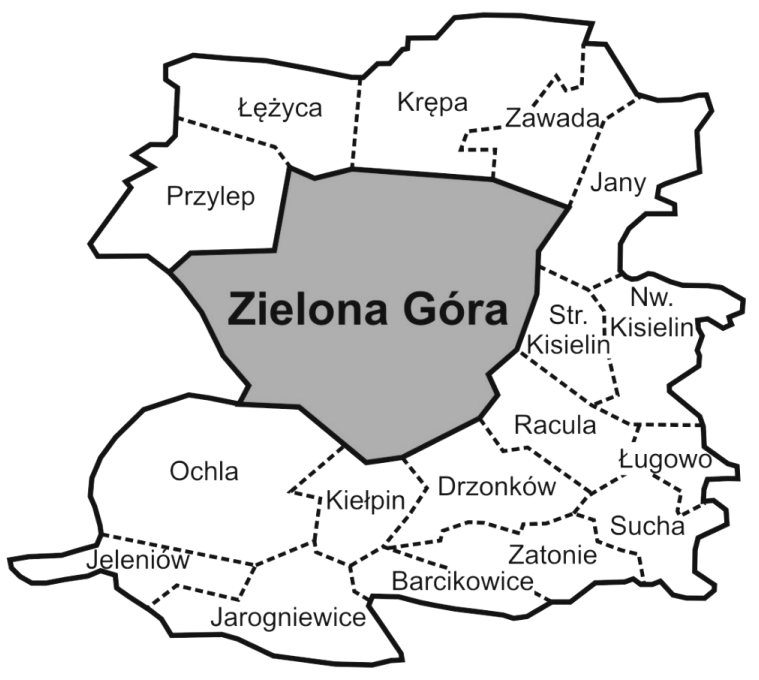

Rys. 9. Miejscowości wcielone do Zielonej Góry w 2015 r. Źródło: opracowanie własne

Jeszcze więcej kontrowersji budzi poszerzenie granic Opola. W 2017 r. do miasta przyłączono sołectwa: Borki, Czarnowąsy, Krzanowice i Świerkle oraz części sołectw: Brzezie (wraz z terenem Elektrowni Opole) i Dobrzeń Mały z gminy Dobrzeń Wielki (powierzchnia - 27,5 km², 5089 - ludność), sołectwa: Sławice, Wrzoski i część Karczowa z gminy Dąbrowa (powierzchnia - 16,7 km², 1480 mieszkańców), sołectwa: Chmielowice i Żerkowice z gminy Komprachcice (powierzchnia - 5,3 km², 2072 ludności), a także sołectwo Winów z gminy Prószków (powierzchnia - 2,8km², 680 mieszkańców) (rys. 10). Spowodowało to powiększenie powierzchni miasta o $52,33 \mathrm{~km}^{2}$ i wzrost jego liczby ludności o 9321 osób. Wniosek obejmował również propozycję wcielenia $w$ granice Opola solectwa Zawada (wraz $z$ terenem centrum handlowego Turawa Park) z gminy Turawa ${ }^{3}$. W uzasadnieniu do rozporządzenia wymieniane były następujące argumenty przemawiające za poszerzeniem granic miasta:

1) przesuwanie się zasobów demograficznych i społecznych Opola do gmin sąsiednich;

2) zacieranie się granic między Opolem a terenami przyległymi;

3) wysoki stopień powiązania funkcjonalnego obszarów podmiejskich z Opolem;

4) rozszerzenie strefy przemysłowo-usługowej i mieszkalnictwa rezydencjonalnego;

5) uporządkowanie i lepsze wykorzystanie przestrzeni publicznej podmiejskich osiedli;

6) prorozwojowe wykorzystanie środków pochodzących z podatków (zwłaszcza z Elektrowni Opole). 


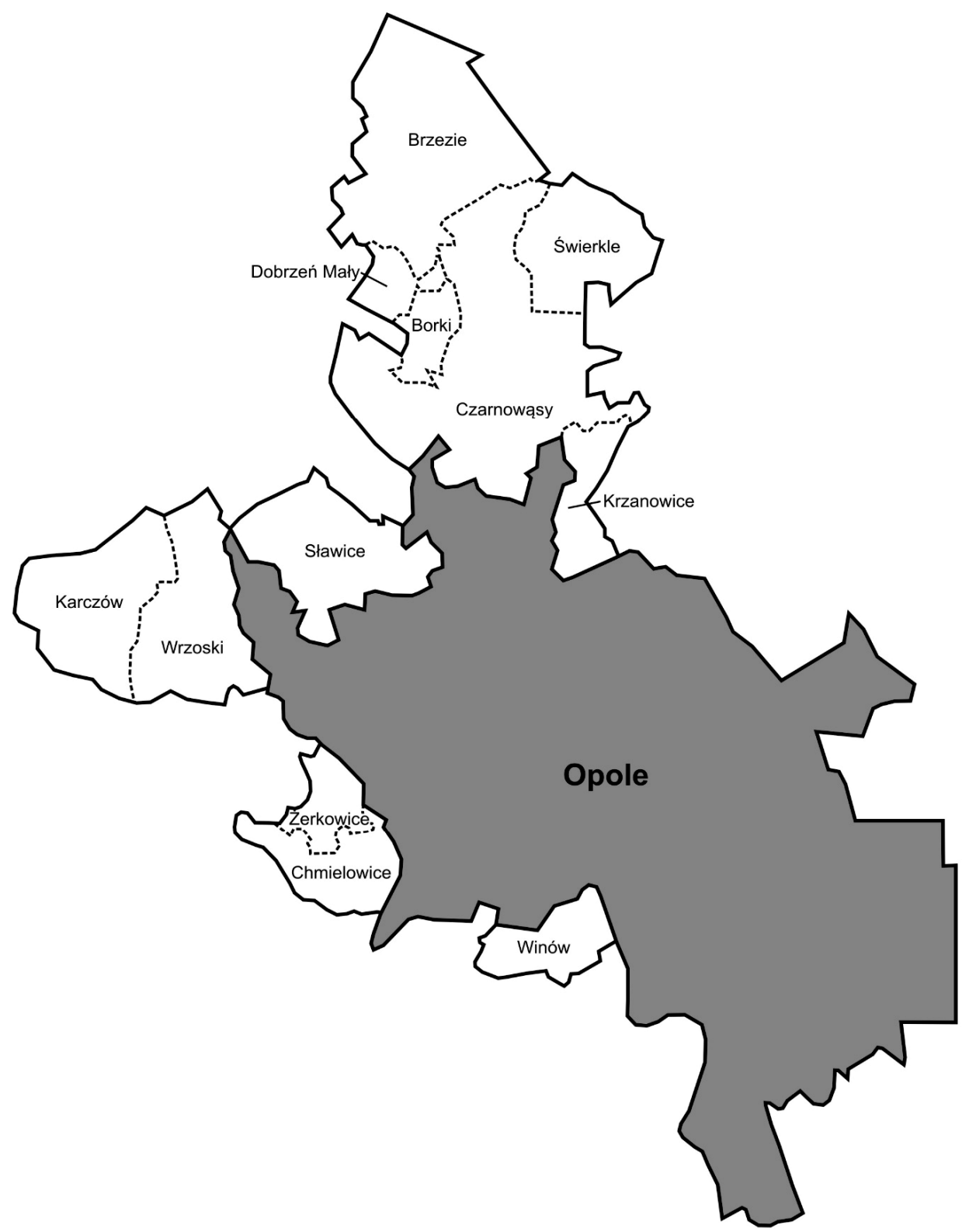

Rys. 10. Miejscowości wcielone do Opola w 2017 r.

Źródło: opracowanie własne

Co istotne, proponowana zmiana została rekomendowana do pozytywnego rozpatrzenia, mimo wyraźnego sprzeciwu lokalnych społeczności. We wszystkich solectwach wcielonych do Opola zdecydowana większość mieszkańców (ponad 90\%) $\mathrm{w}$ trakcie konsultacji społecznych opowiedziała się przeciw inkorporacji (Rajchel, 2018). Mieszkańcy organizowali także marsze protestacyjne, blokady dróg, manifestacje, a w gminie Dobrzeń Wielki nawet strajk głodowy. Konflikt między władzami Opola a władzami ościennych gmin trwa nadal. Jego zarzewiem jest utrata przez podopolskie gminy znacznej części dochodów (dotyczy to w szczególności gminy Dobrzeń Wielki) i utrata przywile- jów przysługujących mniejszości niemieckiej zamieszkującej na terenie wcielonych do miasta wsi (Dimitrow, 2017; Janowski, 2016, 2017, 2018; Józefiak, 2018).

Przypadek Opola, Rzeszowa i Zielonej Góry jest w pewnym sensie podobny. Wszystkie te miasta są w gronie najmniejszych pod względem liczby mieszkańców miast wojewódzkich. W dodatku leżą one w zasięgu oddziaływania ośrodków makroregionalnych (Zielona Góra - Wrocławia i Poznania, Opole - Wrocławia i Katowic, Rzeszów - Krakowa). Jak wszystkie duże miasta w Polsce w ostatnich latach podlegają one intensywnym procesom suburbanizacji (Lisowski, Grochowski, 2008; Śleszyń- 
ski, 2006), a Opole cechuje się dodatkowo niekorzystną sytuacją demograficzną (Dybowska, 2013; Kantor-Pietraga, 2014; Szczygielski, 2015). Poza tym przed poszerzeniem swoich granic administracyjnych miasta te charakteryzowały się (może z wyjątkiem Opola) względnie niewielką powierzchnią, która w przekonaniu władz lokalnych stanowiła barierę ich dalszego rozwoju. Czynniki te przyczyniły się do zainicjowania działań na rzecz poszerzenia granic administracyjnych miasta, których celem było zwiększenie ich potencjału (głównie przez pozyskanie nowych terenów pod inwestycje) i stworzenie większych możliwości konkurowania z największymi ośrodkami miejskimi w kraju. W opinii Habera (2017) przypadek Opola, Rzeszowa i Zielonej Góry wskazuje również na próbę powiązania powiększenia terytorium miasta $\mathrm{z}$ koncepcją zrównoważonego rozwoju. Mają o tym świadczyć publiczne wypowiedzi prezydentów tych miast, w których podkreślane są kwestie potrzeby rozwoju gospodarczego, występowania ugruntowanych od lat więzi społecznych, jednolitego sposobu zarządzania obszarem czy też wpływu powiększenia stolicy województwa na rozwój okolicznych gmin i całego regionu.

\section{DYSKUSJA}

Wraz z przywróceniem samorządności lokalnej w 1990 r. (Kaczmarek, 2005; Runge, 2005) istotną rolę $\mathrm{w}$ procesie decyzyjnym $\mathrm{w}$ zakresie zmian granic administracyjnych jednostek podziału terytorialnego ( $w$ tym miast) przypisano wynikom konsultacji społecznych (Sobota, Jawecki, Tokarczyk-Dorociak, 2012). Takie podejście, w zamyśle ustawodawcy, ma odróżniać okres po 1989 r. od okresu socjalistycznego, w którym zmiany granic administracyjnych przeprowadzane były w wyniku odgórnych decyzji politycznych, często bez akceptacji (a nawet mimo sprzeciwu) społeczności lokalnych. Przyczyniło się to do małej trwałości jednostek powstałych w sposób sztuczny (tzn. niezależnie od kierunków rozwoju przestrzennego miasta), np. miast-zlepieńców i zlepieńców miejsko-wiejskich (Szmytkie, 2005, 2009, 2014). Co więcej, dążenia secesyjne inicjowane były zaraz po wprowadzeniu Ustawy o samorzadzie gminnym (Jarczewski, 2002; Szczepański, 1991, 1996). Proces ten został w pewnym sensie zahamowany wraz $\mathrm{z}$ reformą administracyjną kraju w 1999 r., co wynika z konieczności dostosowania się jednostek podziału teryto- rialnego do nowych realiów. Kolejny trend zmian granic administracyjnych miast jest związany z wejściem Polski w struktury europejskie w 2004 r. Możliwość skorzystania z dodatkowych środków unijnych przeznaczonych dla obszarów wiejskich zainicjowała dążenia secesyjne $\mathrm{w}$ przypadku miejscowości o wiejskim charakterze, funkcjonujących w granicach administracyjnych miast, co przyczyniło się do rozpadu kilku tzw. zlepieńców miejsko-wiejskich (Szmytkie, 2016). Tym bardziej mogą zaskakiwać obserwowane $\mathrm{w}$ ostatnich latach procesy inkorporacji podmiejskich wsi w granice pobliskich miast wojewódzkich (przypadek Opola, Rzeszowa i Zielonej Góry), które są przeprowadzane pomimo wyraźnego sprzeciwu lokalnych społeczności. Po pierwsze ignorowanie opinii mieszkańców i styl podejmowanych decyzji kłócą się z ideami znajdującymi się u podstaw samorządności lokalnej, a także uniemożliwia realizacje potrzeby samostanowienia (por. Kaczmarek, 2016). Po drugie zmiana granic administracyjnych miasta powinna przynosić korzyści dla wszystkich stron objętych proponowaną zmianą. W tym przypadku korzyści są jednostronne - miasto zwiększa swój potencjał demograficzny, zyskuje dodatkowe terytorium i środki finansowe pochodzące $\mathrm{z}$ podatków, a straty $\mathrm{w}$ gminach podmiejskich, z uwagi na ich skalę, są zdecydowanie bardziej dotkliwe. Dobrze obrazuje to przykład gminy Dobrzeń Wielki. W wyniku poszerzenia granic Opola w 2017 r. gmina ta straciła 30,2\% swojego terytorium i 34,9\% ogółu mieszkańców, a dochody jej budżetu (po stracie największego podatnika w postaci Elektrowni Opole) zmniejszyły się z 69,6 mln zł w 2016 r. do 44,6 mln zł w 2017 r. Po trzecie inkorporacja terenów podmiejskich $\mathrm{w}$ granice miasta niesie ryzyko niekontrolowanego zwiększenia powierzchni zabudowanej (por. Bazan-Krzywoszańska, Mrówczyńska, Skiba, 2015).

\section{PODSUMOWANIE}

Po 1989 r. intensywność zmian granic administracyjnych miast w Polsce znacząco zmniejszyła się w stosunku do okresu poprzedzającego (lata 19451989). Co więcej, występujące w tym okresie procesy inkorporacji w większości przypadków miały charakter jedynie korekt granic administracyjnych, związanych z przyłączeniem terenów wcześniej faktycznie zajętych już przez miasto. Analizując pozostałe przypadki zmian administracyjnych można wyróżnić trzy zasadnicze tendencje: rozpad miast- 
-zlepieńców (np. „Wielkie Tychy”, Wodzisław Śląski), rozpad zlepieńców miejsko-wiejskich (Szczawnica, Czarna Woda, Władysławowo, Pieszyce, Jastarnia) $\mathrm{i}$ wcielanie $\mathrm{w}$ granice miast podmiejskich wsi (np. Opole, Rzeszów, Zielona Góra). Pierwsze dwa procesy są związane $\mathrm{z}$ dezintegracją form o niespójnym charakterze powstałych "na wyrost”, głównie w latach 70. XX w., stąd ich rozpad należy oceniać pozytywnie, zwłaszcza w kontekście odzyskania samodzielności administracyjnej przez jednostki wyłączone $\mathrm{z}$ granic wspomnianych miast. Trzeci proces, powiększanie miast o tereny podmiejskie, budzi znacznie więcej kontrowersji. Dotyczy to w szczególności okoliczności towarzyszących zmianom i stylu podejmowanych decyzji. Procesy inkorporacji są bowiem przeprowadzane pomimo wyraźnego sprzeciwu lokalnych społeczności, co kłóci się z ideami stojącymi u podstaw samorządności lokalnej i potęguje poczucie niesprawiedliwości społecznej.

\section{PRZYPISY}

${ }^{1}$ Z wyjątkiem lat 2006-2010, w których wystąpił dodatni przyrost naturalny.

2 W 1977 r. obszar miasta i gminy Imielin został wcielony w granice miasta Mysłowice.

3 Propozycja ta, z uwagi na możliwość niewypłacalności gminy Turawa, została jednak odrzucona.

\section{BIBLIOGRAFIA}

Adamski, F. (2017). Nowa Huta na tle procesów urbanizacyjnych Polski powojennej. Roczniki Nauk Społecznych, 3, s. 223237.

Bazan-Krzywoszańska, A., Mrówczyńska, M., Skiba, M. (2015). Połączenie terenów miasta i gminy Zielona Góra w świetle problemu rozlewania się miast. Logistyka, 2015 (4), s. 24332441.

Dimitrow, R. (2017). Marek Leja, wójt gminy Dąbrowa: „Powiększenie Opola uszczupliło nasz budżet". Nowa Trybuna Opolska, 14 listopada.

Dybowska, J. (2013). Przemiany demograficzne w regionie o nasilonej migracji zagranicznej na przykładzie województwa opolskiego. Studia i Monografie, 487. Opole: Uniwersytet Opolski.

Haber, G. (2017). Koncepcja zrównoważonego rozwoju jako wyzwanie dla polityki miejskiej na przykładzie realizacji projektu „Dużego Opola” w XXI wieku. Zeszyty Naukowe Politechniki Śląskiej. Organizacja i Zarządzanie, 106, s. 153-164.

Janowski, A. (2016). Wójtowie są w szoku. Zapowiadają, że nie zrezygnują z walki. Nowa Trybuna Opolska, 9 lipca.

Janowski, A. (2017). Większe Opole. Jest nowy pomysł na zmianę granic. Nowa Trybuna Opolska, 26 czerwca.

Janowski, A. (2018). Większe Opole. Rząd musi rozstrzygnąć spór pomiędzy Opolem i Dobrzeniem Wielkim. Nowa Trybuna Opolska, 9 kwietnia.
Jarczewski, W. (2002). Odzyskana niezależność. Przyczyny i skutki powstania nowych gmin na obrzeżach GOP w latach 90. Kraków: Wyd. Dante.

Jelonek, A., Zborowski, A. (1992). Wpływ zmian funkcji administracyjnych na rozwój ludnościowy i terytorialny miast w Polsce. W: Funkcja administracyjna miast (s. 27-35), Folia Geographica, 17. Łódź: Uniwersytet Łódzki.

Jęczmionka, P., Koziołek, K. (2015). Co mieszkańcy Zielonej Góry zyskali na połączeniu miasta z gminą? Sprawdź!. Gazeta Wielkopolska, 17 marca.

Józefiak, B. (2018). Zaborcy i złodzieje. Tak o władzach Opola mówią mieszkańcy wsi, które zostały przyłączone do miasta, http:/ / weekend.gazeta.pl/weekend/1,152121,23868333, zaborcy-i-zlodzieje-tak-o-wladzach-opola-mowia-mieszkancywsi.html. Pobrano: 8.09.2018.

Kaczmarek, T. (2005). Struktury terytorialno-administracyjne $i$ ich reformy w krajach europejskich. Poznań: Wyd. Naukowe UAM.

Kaczmarek, T. (2016). Gminny podział administracyjny w świetle 25 lat funkcjonowania samorządu terytorialnego $\mathrm{w}$ Polsce. Przegląd Politologiczny, 1, s. 63-80.

Kalinowski, L. (2018). Jak się nam żyje po połączeniu miasta Zielona Góra z gminą, czyli w którą stronę podążamy. Gazeta Lubuska, 17 marca.

Kantor-Pietraga, I. (2014). Systematyka procesu depopulacji miast na obszarze Polski od XIX do XXI wieku. Katowice: Wyd. Uniwersytetu Śląskiego.

Krzaklewski, S. (2008). Powiększyć miasto. Czasopismo Techniczne. Architektura, 105 (3-A), s. 127-133.

Lisowski, A., Grochowski, M. (2008). Procesy suburbanizacji. Uwarunkowania, formy, konsekwencje. Biuletyn KPZK PAN, 240 (1), s. 216-280.

Powierzchnia i ludność w przekroju terytorialnym. Informacje i opracowania statystyczne (1994-2018). Warszawa: GUS.

Powierzchnia i ludność w przekroju terytorialnym. Informacje i opracowania statystyczne (2009). Warszawa: GUS.

Rajchel, D. (2018). Zmiana granic administracyjnych miasta metodą pokonania bariery przestrzennej na przykładzie Opola i Rzeszowa. W: Sitek S. (red.), "Stare i nowe” problemy badawcze w geografii spoteczno-ekonomicznej, 8, (s. 85-102). Katowice: PTG Oddział Katowicki, Sosnowiec: Uniwersytet Śląski.

Rocznik statystyczny Rzeczypospolitej Polskiej. 2017 (2017). Warszawa: GUS.

Runge, J. (2005). Urbanizacja i jej konsekwencje w regionie katowickim - mity a rzeczywistość. W: I. Jażdżewska (red.), Wspótczesne procesy urbanizacji i ich skutki (s. 193-202). XVIII Konwersatorium Wiedzy o Mieście. Łódź: Uniwersytet Łódzki.

Sikora, A., Hrehorowicz-Gaber, H. (2017). Przekształcenia nowych terytoriów miejskich na przykładzie Rzeszowa. Czasopismo Inżynierii Lądowej, Środowiska i Architektury, 64 (4/I), s. 315-322.

Sobota, M., Jawecki, B., Tokarczyk-Dorociak, K. (2012). Aspekty prawne zmiany granic administracyjnych gmin. Barometr Regionalny, 4 (33), s. 31-38.

Spórna, T. (2012). Modele przemian urbanizacyjnych w województwie śląskim. Sosnowiec: Uniwersytet Śląski.

Stawiarz, K. (2013). Projekt Kontraktu Zielonogórskiego gotowy. Co obiecuje miasto? Gazeta Wyborcza. Zielona Góra, 7 czerwca.

Szczepański, M.S. (1991). „Miasto socjalistyczne” i świat społeczny jego mieszkańców. Rozwój Regionalny - Rozwój Lokalny - Samorzą Terytorialny, 32.

Szczepański, M.S. (red.) (1996). Tychy 1939-1993. Monografia miasta. Tychy.

Szczygielski, K. (2015). Opolska specjalna strefa demograficzna - kaprys czy konieczność? Studia Ekonomiczne, 223, s. 57-72. 
Szmytkie, R. (2003). Znaczenie osiedli miejskich w kształtowaniu systemu osadniczego Polski w okresie powojennym. Czasopismo Geograficzne, 74 (1-2), s. 59-77.

Szmytkie, R. (2005). Dezintegracja miast-zlepieńców. W: I. Jażdżewska (red.), Wspótczesne procesy urbanizacji $i$ ich skutki (s. 379-387), XVIII Konwersatorium Wiedzy o Mieście. Łódź: Uniwersytet Łódzki.

Szmytkie, R. (2005/6). Zlepieńce miejsko-wiejskie jako gminy miejskie w Sudetach. W: K. Heffner, T. Marszał (red.), Mate miasta - studium przypadków (s. 173-184). Łódź: Uniwersytet Łódzki.

Szmytkie, R. (2009). Miasta-zlepieńce na Śląsku Dolnym i Opolskim. Rozprawy Naukowe Instytutu Geografii i Rozwoju Regionalnego, 6. Wrocław: Uniwersytet Wrocławski.

Szmytkie, R. (2014). Procesy inkorporacji i secesji miast w Polsce po 1945 r. W: K. Kuć-Czajkowska, M. Sidor (red.), Miasta, aglomeracje, metropolie w nurcie globalnych przemian (s. 177200). Lublin: Uniwersytet Marii Curie-Skłodowskiej.
Szmytkie, R. (2016). Dezintegracja zlepieńców miejsko-wiejskich w Polsce w latach 2008-2016. Prace Geograficzne, 147, s. 145-168.

Szymańska, D., Grzelak-Kostulska, E., Hołowiecka, B. (2006).

Zmiany powierzchni i gęstości zaludnienia miast Polski w latach 1960-2003. W: J. Słodczyk, E. Szafranek (red.), Kierunki przeksztatceń struktury gospodarczej $i$ społeczno-demograficznej miast (s. 341-353). Opole: Wyd. Uniwersytetu Opolskiego.

Szymańska, D., Grzelak-Kostulska, E., Hołowiecka, B. (2009). Polish towns and the changes in their areas and population densities. Bulletin of Geography. Socio-economic Series, 11, s. 15-30.

Śleszyński, P. (2006). Demograficzny wymiar procesów suburbanizacji w Polsce po 1989 roku. W: S. Kozłowski (red.), Żywiotowe rozprzestrzenianie sie miast (s. 105-124). Białystok: Wyd. Ekonomia i Środowisko.

Zmiany administracyjne miast 1945-1984 (1985). Statystyka Polski. Statystyka Regionalna, 7. Warszawa: GUS.

Artykuł wpłyną:

7 września 2019

Zaakceptowano do druku:

19 października 2019 